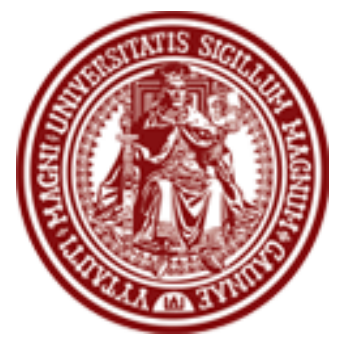

BALTIC JOURNAL OF LAW \& POLITICS

VOLUME 6, NUMBER 1 (2013)

ISSN 2029-0454

http://www.degruyter.com/view/j/bjlp

Cit.: Baltic Journal of Law \& Politics 6:1 (2013): 1-26

DOI: $10.2478 / b j l p-2013-0001$

\title{
MERGER REMEDIES IN A SMALL MARKET ECONOMY: EMPIRICAL EVIDENCE FROM THE BALTIC STATES
}

\author{
Alexandr Svetlicinii \\ Senior Researcher \\ Tallinn University of Technology, Tallinn Law School (Estonia) \\ Contact information \\ Address: Akadeemia tee 3, 12618 Tallinn, Estonia \\ Phone: +372620 2422 \\ E-mail address: alexandr.svetlicinii@ttu.ee
}

\section{Külliki Lugenberg}

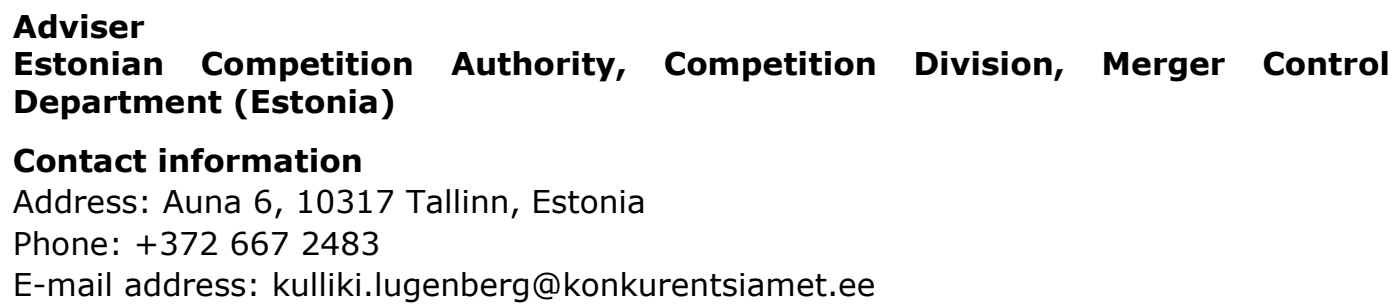

Received: February 4, 2013; reviews: 2; accepted: May 20, 2013.

\begin{abstract}
The paper represents a comparative study of the merger remedies practices of the three Baltic states: Estonia, Latvia and Lithuania. Based on comprehensive merger control data (2004-2011) and a comparative assessment of merger remedies imposed by the NCAs in the selected economic sectors (telecoms, alcoholic beverages, construction materials, trade in pharmaceuticals) the study identifies trends and tendencies of merger control that are characteristic for small market economies. Despite harmonization of national competition laws and enforcement practices with the EU rules and standards, the study highlights an obvious divergence from the EU guidance expressed in increasing acceptance of behavioral commitments. The results of the assessment indicate the need to develop more specific
\end{abstract}


guidance on behavioral remedies that would better reflect the merger control realities of small market economies.

\section{KEYWORDS}

EU competition law, merger control, merger remedies, national competition authority, Estonia, Latvia, Lithuania

\section{NOTE}

The present research was carried out with the support of the European Social Fund, under the framework of the researcher mobility programme Mobilitas, administered by the Estonian Research Council. The information and views set out in this article are those of the authors and do not necessarily reflect the official opinion of the Estonian Competition Authority or the Estonian Research Council. The authors wish to thank Jūlija Linkeviča, Rita Teclofa and Vadims Šeršnovs from the Latvian Competition Council and Gintare Izokaitytè from the Competition Council of the Republic of Lithuania for providing empirical data on merger control in Latvia and Lithuania respectively. Special thanks go to Frode Steen for valuable comments on the paper delivered at the 7th PhD Workshop of the Competition Law and Economics European Network hosted by the Bergen Center for Competition Law and Economics on 13-14 May 2013. 


\section{INTRODUCTION}

The enforcement of competition rules including merger control remains one of the most important EU policies contributing to the functioning of the Internal Market, strengthening the competitiveness of the European economies and according wider choice and lower prices to consumers. The EU has consistently required that the candidate countries become accustomed to a competition framework similar to that of the EU well before the date of accession. The Baltic countries (Estonia, Latvia and Lithuania) all adopted their competition laws more than ten years prior to their accession to the EU in $2004 .{ }^{1}$ In the field of merger control the Baltic jurisdictions have been closely following the EU developments and after the adoption of the new EU Merger Regulation (EUMR), ${ }^{2}$ which modified the substantive test used for the appraisal of concentrations, all three countries introduced respective amendments in their competition legislation. ${ }^{3}$ The reform of competition laws in these countries was also inspired by the case law of the Court of Justice of the European Union (CJEU). ${ }^{4}$

The harmonization of the national legislation with EU standards and practices has signalled the intention of the Baltic states to follow the EU's guidance in the domestic competition enforcement. ${ }^{5}$ At the same time some authors have questioned the extent to which the implementation of the EU competition rules in these countries should take into account the local circumstances such as the size of the economy. ${ }^{6}$ According to Gal, the prevalence of the concentrated market structures in a small market economy requires a distinct set of rules that would

\footnotetext{
${ }^{1}$ See, e.g., Oliver Black, "Competition law in Central and Eastern Europe," E.C.L.R. 14(3) (1993): 129; Martti Kalaus, "Estonia: the new Competition Act introduces full merger control," E.C.L.R. 23(6) (2002): 304.

${ }^{2}$ Regulation no. 139/2004 on the control of concentrations between undertakings, Official Journal (2004, L24/1).

3 For the discussion on reform of the merger control regimes in the Baltic countries see Jurgita Malinauskaite, "Development of merger control in the Baltic countries: over 10 years of experience: Part 2," E.C.L.R. 32(3) (2011): 109.

${ }_{4}$ The Estonian Competition Act reads as follows: "For the purposes of this Act, an undertaking in a dominant position is undertaking which accounts for at least $40 \%$ of the turnover of the goods market or whose position enables the undertaking to operate in the market to an appreciable extent independently of competitors, suppliers and buyers" (Competition Act of the Republic of Estonia, Official Gazette (2001, no. 56, 332), Article 13(1)). This wording was inspired by the definition of dominance given in HoffmannLa-Roche \& Co. AG v Commission, CJEU (1979, no. 85/76) and United Brands Company and United Brands Continentaal BV $v$ Commission, CJEU (1978, no. 27/76).

${ }^{5}$ For example, some authors note that "there is hardly anything in EU competition law that has not found its way into the Estonian Competition Act, often even word for word" (see Julia Thielert and Maarten Pieter Schinkel, "Estonia's competition policy: a critical evaluation towards EU accession," E.C.L.R. 24(4) (2003): 165). Similarly, the Lithuanian competition law reform was seeking to integrate the EU standards and practices (see Dalia Virtanen, "The new Competition Act in Lithuania," E.C.L.R. 21(1) (2000): 30).

${ }^{6}$ See Damien Geradin and David Henry, "Competition Law in the New Member States - Where Do We Come From? Where Do We Go?": 30; in: Damien Geradin, ed., Modernisation and Enlargement: Two Major Challenges for EC Competition Law (Intersentia, 2005); Henrik Horn and Johan Stennek, "EU merger control and small member states interests"; in: Pros and Cons of Merger Control (Konkurrensverket, 2002).
} 
regulate the conduct of market players: "the need for different rules arises from the existence of one-size-fits-all formulations that are based on general presumptions about market conduct, which are informed, in turn, by the natural conditions of the market. Small size affects competition laws from their goals to their rules of thumb". ${ }^{7}$ In the field of merger control, small economies can be guided by the same substantive standards as the large ones. ${ }^{8}$ However, the choice of goals that a merger control should pursue in a particular jurisdiction can result in a distinct enforcement practice. For example, it has been argued that in a small market economy the competition authorities should exhibit greater flexibility in relation to the commitments that can be proposed by the merging parties in order to get their concentration cleared. ${ }^{9}$

The works that analyze the enforcement of merger control in the Baltic countries have been few in number ${ }^{10}$ and the present paper aims at filling this gap by providing a comparative study on the merger remedies practices in these jurisdictions. The present work attempts to verify whether the trends and tendencies in merger remedies enforcement in the Baltics support the above mentioned policy statements related to the design of merger control in the small market economies and their consistency with the EU standards and practices. It is based on the analysis of the individual merger decisions issued by the national competition authorities (NCAs) of Estonia (EECA), ${ }^{11}$ Latvia (LVCA) ${ }^{12}$ and Lithuania (LTCA), ${ }^{13}$ as well as on the statistics of merger control enforcement in these countries in 2004-2011 (starting from the year when they became the Member States of the EU). ${ }^{14}$

In order to place the study in the EU and international context, the paper first provides an overview of the ongoing discussion on the types of remedies that are appropriate in various legal, economic and institutional settings. Secondly, it analyzes the statistical data on merger enforcement in the Baltic countries. Thirdly, we compare the approaches followed by the Baltic NCAs in the following four economic sectors: (1) telecommunications; (2) alcoholic beverages;

\footnotetext{
7 Michal S. Gal, Competition Policy for Small Market Economies (Harvard University Press, 2003), p. 4.

${ }^{8}$ See Katri Paas-Mohando, "Do Small Economies Need Specific Rules for Substantive Aspects of Merger Control?" E.C.L.R. 34(5) (2013): 266.

9 See Katri Paas, "Implications of the Smallness of an Economy for Merger Remedies," Juridica International XV (2008): 102. The same has been argued in relation to the micro economies (see Michal S. Gal, "Merger Policy for Small and Micro Jurisdictions": 120; in: More Pros and Cons of Merger Control (Konkurrensverket, 2012)).

${ }^{10}$ See Jurgita Malinauskaite, "Efficiency tests in the merger control regimes of the Baltic countries: myth or reality," I.C.C.L.R. 18(4) (2007): 136; Carri Ginter and Mari Matjus, "Assessment of non-horizontal mergers in Estonia," E.C.L.R. 31(12) (2010): 504; Alexandr Svetlicinii and Külliki Lugenberg, "Merger remedies in a small market economy: the Estonian experience," E.C.L.R. 33(10) (2012): 475.

${ }^{11}$ Estonian Competition Authority (Konkurentsiamet) (EECA); website: http://www.konkurentsiamet.ee/.

12 Latvian Competition Council (Konkurences padome) (LVCA); website: http://www.kp.gov.lv/.

13 Competition Council of the Republic of Lithuania (Konkurencijos taryba) (LTCA); website: http://kt.gov.lt/.

${ }_{14}$ The merger control data from the three Baltic countries is reproduced in the Annex 1.
} 
construction materials; and (4) wholesale and retail trade in pharmaceuticals. Finally, we conclude our analysis by summarizing the identified enforcement trends and formulate certain policy recommendations aimed at harmonizing the merger remedies practices in the Baltic countries and encouraging further research and collaboration in this domain.

\section{MERGER REMEDIES FOR A SMALL MARKET ECONOMY: STRUCTURAL}

\section{OR BEHAVIORAL?}

The analysis of the EU merger remedies practice suggests that the EU Commission in its more than 300 merger remedies decisions has consistently focused on the effectiveness of the proposed commitments. ${ }^{15}$ As a result, the EU Commission's 2008 Remedies Notice ${ }^{16}$ exhibits the general preference for the structural remedies. ${ }^{17}$ Behavioral commitments without an effective monitoring mechanism should be considered as mere declarations of intention by the parties and would not amount to binding obligations because their breach would not result in the revocation of the decision. ${ }^{18}$ Although this does not exclude the behavioral remedies per se, those "can only exceptionally be accepted if their workability is fully ensured by effective implementation and monitoring". ${ }^{19}$ The same preference is noted in the UK Competition Commission's 2008 Guidelines on Merger Remedies. ${ }^{20}$ A study summarizing more than 700 national and EU cases related to merger remedies concluded that there is an overall preference for structural remedies in the majority of the national competition authorities in the EU. ${ }^{21}$ At the same time, it should be noted that in certain industries, such as

${ }^{15}$ See Nadia Calvino, "When do Mergers Raise Concerns? An Analysis of the Assessment Carried out by the European Commission under the New Merger Regulation," Journal of European Competition Law \& Practice, 2(6) (2011): 527.

${ }_{16}$ Commission Notice on remedies acceptable under the Council Regulation (EC) No 139/2004 and under Commission Regulation (EC) No 802/2004, Official Journal (2008, C 267).

17 Ibid., Article 13: "the commitments which are structural in nature, such as the commitment to sell a business unit, are, as a rule, preferable from the point of view of the Merger Regulation's objective, inasmuch as such commitments prevent, durably, the competition concerns which would be raised by the merger as notified, and do not, moreover, require medium or long-term monitoring measures".

${ }_{18}^{18}$ Ibid., Article 13.

19 Ibid., Article 17.

20 Competition Commission, CC8 - Merger Remedies: Competition Commission Guidelines (November 2008), pp. 14-15//

http://www.competition-commission.org.uk/assets/competitioncommission/docs/pdf/non-

inquiry/rep_pub/rules_and_guide/pdf/cc8.pdf (accessed February 2, 2013): "in merger inquiries, the CC will generally prefer structural remedies, such as divestiture or prohibition, rather than behavioral remedies because ... (b) behavioral remedies may not have an effective impact on the SLC and its resulting adverse effects, and may create significant costly distortions in market outcomes; and (c) structural remedies do not normally require monitoring and enforcement once implemented."

${ }^{21}$ See Pranvera Këllezi and Christophe Rapin, "Merger remedies and competition law: An overview of EU and national case law," e-Competitions 43382 (2012). For the experience of particular jurisdictions with merger remedies see e.g. Thomas Hoehn and Suzanne Rab, "UK merger remedies: convergence or conflict with Europe? A comparative assessment of remedies in UK mergers," E.C.L.R. 30(2) (2009): 74; Cormac Little, "Remedies under Irish merger control rules," E.C.L.R. 30(12) (2009): 600; Marieke Baarslag, Gulbahar Tezel, and Saskia Weerheim, "The Dutch merger remedy experience," E.C.L.R. 30(9) (2009): 447. 
telecommunications, the European NCAs have been more receptive towards behavioral commitments than in other economic sectors, such as wholesale and retail. ${ }^{22}$

However, the preference for structural solutions has not remained intact. The recent review of the US Department's of Justice merger remedies policy resulted in the adoption of the 2011 Antitrust Division Policy Guide to Merger Remedies, ${ }^{23}$ which endorsed the application of behavioral remedies in vertical merger cases and in cases with both horizontal and vertical concerns. According to the DoJ's Remedies Guide the behavioral remedies are a "valuable tool" because "they can preserve a merger's potential efficiencies, and, at the same time, remedy the competitive harm that otherwise would result from the merger". ${ }^{24}$

The acceptance of behavioral remedies has been also acknowledged on the international level. The discussion on merger remedies carried out at the 2004 OECD roundtable was concluded with the observation that although there was a general preference for structural remedies, it was not obvious that the latter are more efficient and less costly. ${ }^{25}$ In 2005 the ICN Merger Working Group recommended the application of behavioral remedies under certain circumstances. ${ }^{26}$ At the 2011 OECD roundtable on remedies in merger cases it was pointed out that the success of a structural divestiture depends largely (if not exclusively) on the existence of suitable purchasers interested in acquiring the assets to be divested. ${ }^{27}$ The ongoing financial and economic turmoil has emphasized the fact that there may be circumstances when there are simply no purchasers interested in such assets.

In addition to the general considerations, which can affect the choice of merger remedies, one should also consider the specifics of the domestic market, as well as the institutional capacities and legal powers of the NCAs. It has been argued that in small economies the structural remedies have limited effectiveness as they prevent highly-efficient dominant firms from competing aggressively or from taking

\footnotetext{
22 See Thomas Hoehn, Suzanne Rab, Grant Saggers, "'Breaking up is hard to do': national merger remedies in the information and communication industries," E.C.L.R. 30(5) (2009): 261.

${ }^{23}$ US Department of Justice, Antitrust Division, Policy Guide to Merger Remedies (June 2011) // http://www.justice.gov/atr/public/guidelines/272350.pdf (accessed February 2, 2013).

${ }^{24}$ Ibid., pp. 6-7.

${ }^{25}$ See OECD Directorate for Financial and Enterprise Affairs, Competition Committee, Merger Remedies, Document DAF/COMP(2004)21 (December 2004): $270 / /$ http://www.oecd.org/competition/mergers/34305995.pdf (accessed February 2, 2013).

${ }^{26}$ (a) The divestiture is not feasible (e.g. absence of suitable buyers) and the prohibition is not possible (multi-jurisdictional implications); (b) the expected anti-competitive restraints will be limited in time (e.g. due to the rapid technological developments); (c) the efficiency benefits of the merger are significant (ICN Merger Working Group: Analytical Framework Subgroup, Merger Remedies Review Project, Report for the fourth ICN annual conference (June 2005): 12 //

http://www.internationalcompetitionnetwork.org/uploads/library/doc323.pdf (accessed February 2, 2013)).

27 See OECD Directorate for Financial and Enterprise Affairs, Competition Committee, Merger Remedies, Document DAF/COMP/WP3(2011)2 (October 2011).
} 
advantage of economies of scale. ${ }^{28}$ Since small markets can support only a limited number of competitors, one of the competition policy implications would be to prioritize aggressive antitrust enforcement against anti-competitive agreements (including tacit collusion) and abuses of dominance rather than attempting to regulate market concentration through stringent merger control and structural remedies. From the enforcement point of the view the following problems with structural remedies in small market economies have been used as arguments for greater flexibility as far as the type of remedy is concerned: weak bargaining position vis-à-vis large multinationals and difficulty to enforce divestitures or prohibitions, preservation of efficiencies and other pro-competitive effects of the merger, monitoring costs. ${ }^{29}$ It should be also noted that in small jurisdictions it is sometimes problematic to implement structural remedies simply because the consolidated nature of certain industries excludes most incumbents from being considered as potential purchasers of the divested assets. In light of these constraints, which may limit the use of structural remedies, the NCAs increasingly consider the possibility of accepting behavioral remedies. ${ }^{30}$

\section{COMPARATIVE ANALYSIS OF THE MERGER REMEDIES PRACTICES}

\section{IN THE BALTIC STATES}

The statistics of merger control enforcement in the Baltic countries demonstrate a significant difference in the total number of concentrations notified in Estonia and Latvia on one hand and Lithuania on the other, ${ }^{31}$ which is partly due to the difference in mandatory notification thresholds. ${ }^{32}$

\footnotetext{
28 See Michal S. Gal, "Size Does Matter: General Policy Prescriptions for Optimal Competition Rules in Small Economies," Southern California Law Review 74 (2000-2001): 1437.

${ }^{29}$ Katri Paas, supra note 9: 99-102.

${ }^{30}$ Ibid.: 98.

${ }^{31}$ For the focus period 2004-2011 Estonian and Latvian NCAs received a similar number of merger notifications: 218 and 202 respectively. The number of concentrations notified to the LTCA was much higher - 441.

32 See Jurgita Malinauskaite, "Development of merger control in the Baltic countries: over 10 years of experience: Part 1," E.C.L.R. 32(2) (2011): 77.
} 


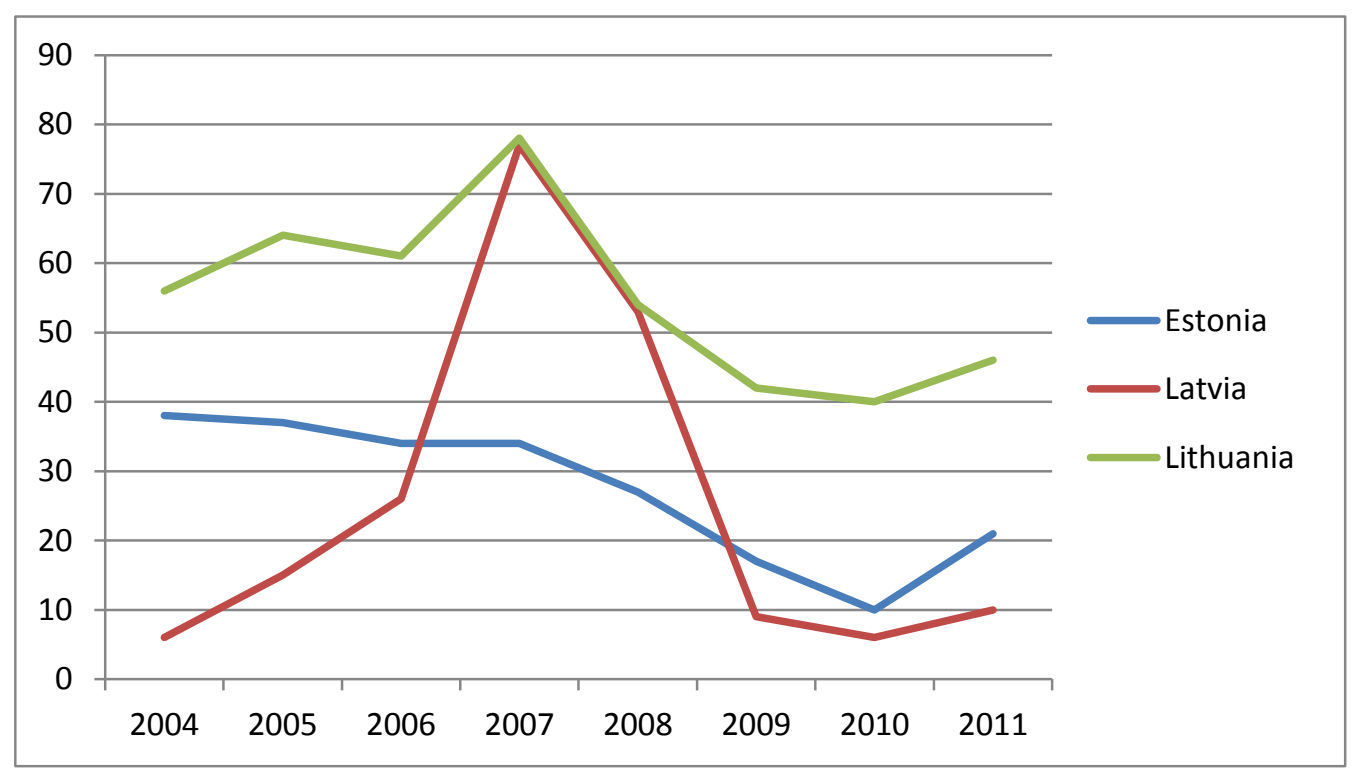

Fig. 1. Notified concentrations (2004-2011)

This, however, did not have a commensurate effect on the proportion of the decisions containing remedies to the total number of the notified concentrations, which does not exceed $10 \%$ in any of the target jurisdictions. ${ }^{33}$

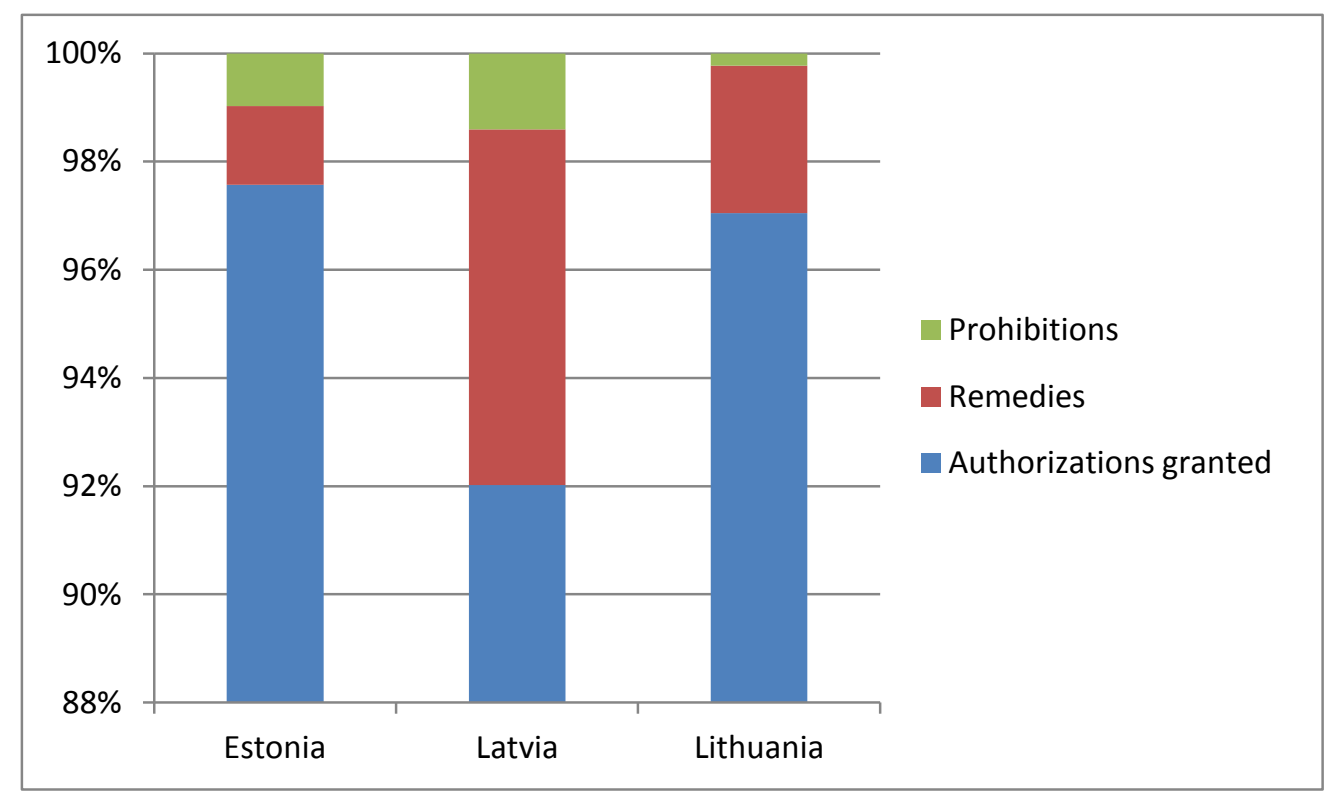

Fig. 2. Types of merger decisions (2004-2011)

When compared according to the type of remedies (structural or behavioral) one cannot conclude that a certain type of remedies prevails. During the focus period 2004-2011 only the EECA reported 2:1 ratio in favor of structural

\footnotetext{
${ }^{33}$ Estonia - 1,4\%, Latvia - 6,9\%, Lithuania - 2,7\%.
} 
remedies, ${ }^{34}$ while in Latvia and Lithuania the competition authorities resorted to behavioral remedies more often than structural ones: the ratios being 9:4 and 7:6 respectively.

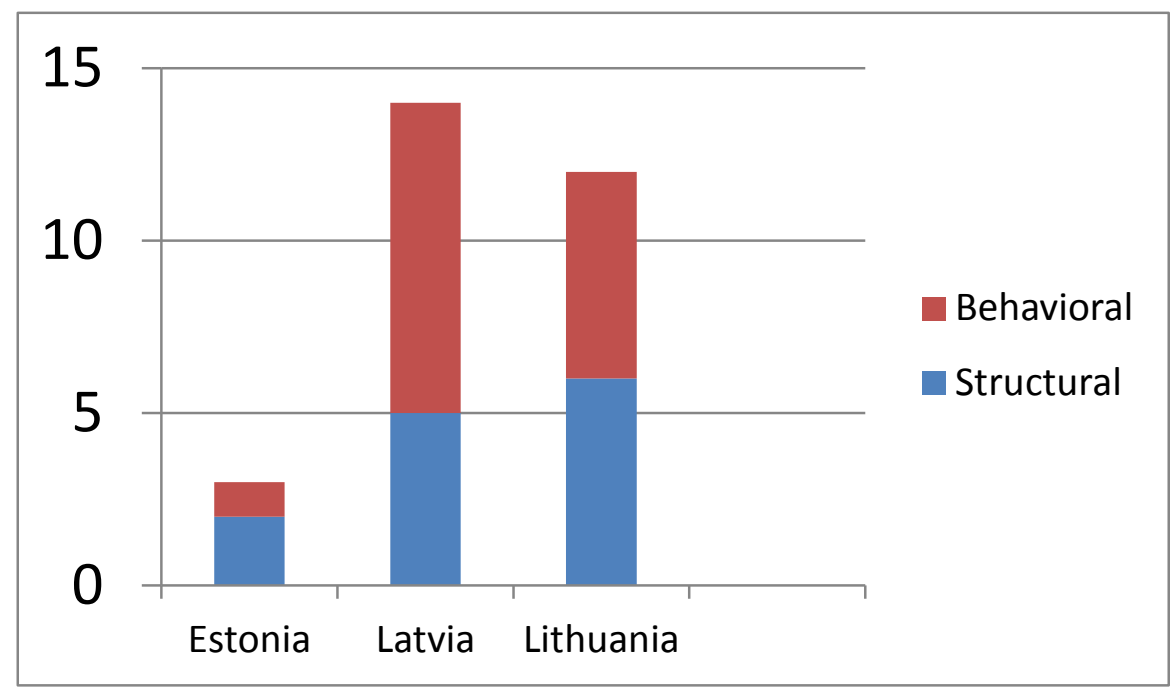

Fig. 3. Types of remedies (2004-2011)

The collected statistics on merger control enforcement in the Baltic countries thus do not support the above mentioned suggestions that competition authorities in small market economies experience substantial difficulties with implementing structural remedies and that behavioral commitments should be accepted as an alternative solution. At the same time, the numbers support the above mentioned policy argument that the small jurisdictions should be flexible enough to accept behavioral commitments where structural divestures could not be achieved due to economic or enforcement reasons.

While the statistics do not identify any clear preference for a certain type of merger remedies in the Baltic countries, the ensuing sections of the present paper should illustrate the above mentioned numbers by comparing the NCAs' approach towards merger remedies on the example of particular economic sectors where competition problems were identical or similar in all of the Baltic states. In order to validate the preliminary findings based on the collected enforcement data we attempted to diversify the pool of the selected markets. It covers the markets for goods and services, consumer goods and industrial products, regulated and nonregulated economic sectors.

\footnotetext{
${ }^{34}$ Even in case of Estonian merger control it would be problematic to argue that the structural remedies are preferred, because during the focus period of 2004-2011 the EECA resorted to merger remedies only in three cases. If 2003 would be also considered, then the EECA's practice would also display a preference for behavioral remedies as in that year there were three concentrations cleared by the EECA with behavioral commitments attached. No structural remedies were applied in that year.
} 


\subsection{TELECOMMUNICATIONS}

From the competition point of view, the markets in the telecommunications sector in the Baltic countries display the characteristic features of a small market economy. For example, in the fixed network markets the incumbent operators in all three Baltic states ${ }^{35}$ enjoy a dominant position and, as a result, the competitive concerns identified by the NCAs in these markets have arisen primarily in relation to the network access and pricing issues. It can be stated generally that in small economies, which are usually dependent on international trade and imported goods, more competition problems arise in the markets where the possibility for trade is non-existing or very limited. This applies for example to sectors of non-tradable goods, such as telecommunications. But at the same time, the small size of the market by itself does not exclude the possibility for effective competition in telecommunications sector. For example, in each of the Baltic states there are several mobile telephone operators, each possessing its own network. ${ }^{36}$ The following examples illustrate how the Baltic competition authorities have approached market access issues in their merger assessment.

The Latvian competition authority first addressed the network access problem in 2002 when it examined the effects of the Telia/Sonera merger, which was conditionally cleared by the EU Commission. ${ }^{37}$ In Latvia, which at that time was not yet a member of the EU, the merger resulted in a monopoly in the market for access to the international telecom services. The divestment of a stand-alone business was under consideration but the LVCA noted that the independent provider still required access to Telia's global telecom network, without which it would be less competitive. The LVCA finally opted for a set of behavioral remedies and imposed network access obligations for the period of three years following the concentration. ${ }^{38}$

The same merger has been reviewed by the competition authority in Lithuania where the merging multinationals were controlling the dominant fixed telecommunications services provider $A B$ Lietuvos telekomas and a significant player in the mobile telecommunications services market $A B$ Omnitel. Although the two markets were not overlapping, the LTCA was concerned about the fact that economies of scale and new technologies would strengthen the position of the merged entity in both markets. The remedy chosen by the LTCA can be labelled

\footnotetext{
${ }^{35}$ In 2011: in Estonia - Elion Ettevõtted AS; in Latvia - Lattelecom; in Lithuania - TEO LT AB.

${ }^{36}$ In Estonia - EMT AS, Elisa Eesti AS and Tele2 Eesti AS; in Latvia - LMT, Bite Latvija and Tele2; in Lithuania - Omnitel UAB, Tele2 UAB and Bite Lietuva UAB.

37 Telia/Sonera, EU Commission (2002, no. COMP/M2803).

38 Telia/Sonera/Swedgiro AB, LVCA (13.08.2002, no. 124); see Dace Silava-Tomsone and Ugis Zeltins, "The Latvian NCA clears a merger in the telecommunications sector with remedies including granting of access to infrastructure (Telia Sonera)," e-Competitions 20973 (2002).
} 
behavioral: the merged entity was obliged not to merge its Lithuanian subsidiaries without the prior approval of the LTCA. ${ }^{39}$ The merged entity complied with its commitments and in 2003 it notified the acquisition of direct control over the largest Lithuanian mobile operator Omnitel. The LTCA continued its practice of imposing behavioral remedies and obliged the acquirer not to merge its fixed and mobile telecommunications subsidiaries without the prior approval of the competition authority. In addition to that, the LTCA imposed certain transparency (separate accounts for fixed telecom services) and non-discrimination obligations concerning network access and interconnection agreements. ${ }^{40}$

The Telia/Sonera merger was also notified in Estonia, where it was cleared by the EECA without remedies. ${ }^{41}$ As a result of the merger, Telia acquired $49 \%$ of the share capital of AS Eesti Telekom, which was not sufficient to obtain sole control. The shareholders' agreement of AS Eesti Telekom provided that TeliaSonera $A B$ alone or jointly with other undertakings did not have the right to acquire sole control before 2004. The incumbent fixed telecommunications operator Elion Ettevõtted $A S$ and the leading mobile telephone operator AS EMT belonged to AS Eesti Telekom already prior to the Telia/Sonera merger. The market horizontally affected by the merger was the market for provision of telecommunication system solutions and no significant competition concerns were identified by the EECA in that sector.

In Estonia the problem of network access was addressed by the EECA in 2005 when the incumbent telecom operator Elion Ettevõtted, which owned $96 \%$ of the nation-wide broadband access network, set out to acquire MicroLink, an independent operator with its own fiber-optic broadband access network based on the Ethernet technology. The EECA arrived to the conclusion that, as a result of the proposed concentration, the incumbent's dominant position in the wholesale and retail markets for broadband access would have been strengthened. The competition between the two largest rivals would have disappeared and other operators would not have a choice in purchasing broadband access in the wholesale market. In order to remove these potential anti-competitive effects, Elion

39 Telia/Sonera, LTCA (18.07.2002, no. 82). Such remedy was hardly necessary as both subsidiaries were substantial market players and their concentration would meet the mandatory notification threshold under the Lithuanian merger control regime (see Agne Makauskaite, "The Lithuanian Competition Council clears a merger in the fixed, mobile and other related telecommunications markets with a commitment to notify any further structural changes (Telia/Sonera)," e-Competitions 21023 (2002)).

40 TeliaSonera/Omnitel, LTCA (11.12.2003, no. 1S-140); see Agne Makauskaite, "The Lithuanian Competition Council clears in phase II a merger in the markets of fixed and mobile communications with structural and behavioural remedies (TeliaSonera/Omnitel)," e-Competitions 21033 (2003).

${ }^{41}$ Telia AB/Sonera Corporation, EECA (25.09.2002, no. 58-KO). 
Ettevõtted committed to divest MicroLink's fiber-optic electronic communications network, including all relevant agreements and know-how. ${ }^{42}$

Since the incumbent telecom operators in all three Baltic countries were controlled by TeliaSonera AB, the acquisition of Microlink Latvia SIA by Lattelecom SIA was also assessed by the LVCA. In Latvia the concentration would allow the incumbent to acquire dominant position on the market for data transmission services. As in Estonia, the LVCA concluded that the divestiture of the target undertaking's assets used for data transmission services would ensure preservation of competition on the relevant market. The assets had to be divested under the following conditions: (1) the purchaser cannot be directly or indirectly related to Lattelecom SIA; (2) Lattelecom SIA cannot encumber the assets to be sold except for a right of Lattelecom SIA to use such assets in order to provide data transmission services and internet services to the current clients of Microlink Latvia SIA. ${ }^{43}$

In Lithuania the situation was different because: (1) the subsidiaries of the merging multinationals were active in the markets for fixed ( $A B$ Lietuvos telekomas was the largest fixed telecommunications services, leased lines and broadband provider) and mobile telecommunications services (UAB Omnitel was the largest provider of mobile telecom services); and (2) unlike in Estonia and Latvia, the Lithuanian UAB Microlink Lietuva did not have its own network and had to lease the lines from $A B$ Lietuvos telekomas. Although the share of UAB Microlink Lietuva was not significant, it was nevertheless one of the major data transmission services providers in Lithuania. The LTCA authorized the concentration Elion/Microlink under condition that Microlink Lietuva would be divested within an established time limit. ${ }^{44}$ Until the divestiture $A B$ Lietuvos telekomas was obliged to maintain viability of the acquired entity, its competitiveness, trademarks and other rights related to the image of UAB Microlink Lietuva. ${ }^{45}$

The above merger remedies experience of the Baltic competition authorities in the field of telecommunications can be summarized as follows. In the case of

42 Elion Ettevõtted AS/MicroLink AS, EECA (21.10.2005, no. 47-KO); see Kaarli Eichhorn, "The Estonian Competition Authority clears a merger in phase II in the markets of wholesale broadband access and retail broadband access with divestiture remedies (Elion/MicroLink)," e-Competitions 20953 (2005).

${ }^{43}$ Lattelecom SIA/Microlink Latvia SIA, LVCA (30.09.2005, no. 497/05/10/3); see Dace Silava-Tomsone, Ugis Zeltins, "The Latvian Competition Council clears a merger in the markets for data transmission services and Internet access services subject to divestiture remedies (Lattelecom/Microlink Latvia)," eCompetitions 20979 (2005).

${ }^{44}$ Elion/MicroLink, LTCA (27.10.2005, no. 1S-122); see Agne Makauskaite, "The Lithuanian Competition Council clears a concentration in the wholesale and retail markets for broadband services with structural and behavioural remedies (Elion/MicroLink)," e-Competitions 21037 (2005).

${ }^{45}$ UAB Microlink Lietuva was divested within the prescribed time-limit and in 2006 it entered with market for fixed telecommunications services offering its "Metro Tel" service in competition with TEO LT AB (former AB Lietuvos telekomas) (see OECD, Directorate for Financial and Enterprise Affairs, Competition Committee, Cross-Border Merger Control: Challenges for Developing and Emerging Economies, Contribution from Lithuania, Document DAF/COMP/GF/WD(2010)74 (December 2010): 7 // http://kt.gov.It/naujienos/docs_oecd/global_forum_2011_1.pdf (accessed February 2, 2013)). 
Telia/Sonera concentration, which involved the consolidation of two large multinationals already present on the Baltic markets, the LVCA and the LTCA have both resorted to behavioral remedies in order to assure network access for independent providers (the concentration did not raise concerns in Estonia). The significance of the concentration (also reviewed by the EU Commission) ${ }^{46}$ could have played a role in the NCAs' decision to abstain from requiring structural divestitures. In the second wave of telecom mergers where local incumbents were acquiring independent operators, all of the Baltic competition authorities have required structural remedies that would allow the preservation of competition in the affected network industries.

\subsection{ALCOHOLIC BEVERAGES}

On the alcoholic beverages markets in the Baltic countries the domestically manufactured products are competing with the imported ones. Foreign producers are usually present in the Baltic markets through their local subsidiaries (distributors and wholesalers), who in turn sell the products to supermarkets, discounters and smaller stores. In the Baltic states the sale of alcoholic beverages (including those with high alcohol content) is not limited to special stores as it is the case in the Nordic countries. ${ }^{47}$ In Estonia, Latvia and Lithuania alcoholic beverages can be bought from any regular retail locations. The above mentioned factors stimulate competition both at the wholesale and retail segments of the market. The merger control in this economic sector encountered both horizontal and vertical concerns. For example, potential competition problems may arise in situations where at the production level there is a dominant undertaking (or undertaking with a significant market power) or when at the wholesale level a single wholesaler has a diverse portfolio with many popular trademarks, which would significantly reduce competition at the wholesale level.

The Estonian merger control accounts for only a single case where merger remedies were accepted in the market for alcoholic beverages. The parties had horizontally overlapping activities in the markets for production and sale of long drink and cider. At the time of the investigation the cider market had been developing fast and expanding. There were no substantial entry barriers and the potential competitors, such as wine and beer producers, submitted to the EECA that they could adapt their production lines for the production of cider. Due to the

\footnotetext{
46 Telia/Sonera, supra note 37.

${ }^{47}$ In Finland, alcoholic beverages stronger than $4,7 \%$ can be sold only in Alko stores (national alcohol retail monopoly), In Sweden, only the state-owned Systembolaget can sell alcoholic beverages stronger than 3,5\%. In Norway, the alcoholic beverages stronger than $4,75 \%$ can be purchased exclusively in Vinmonopolet stores.
} 
above, the EECA was of the opinion that the merging parties would not have the possibility to significantly restrict competition in the cider market. Nevertheless, in its conditional clearance decision ${ }^{48}$ the EECA accepted the parties' commitment not to increase the production volumes of cider for a period of two years following the concentration. ${ }^{49}$

In Latvia, the LVCA was concerned with input foreclosure scenarios where a new vertically integrated company would acquire control over the largest manufacturer of alcoholic beverages in Latvia. In order to prevent the exclusion of competing retailers, the LVCA decided to resort to behavioral remedies. It has obliged the merged entity for the period of five years: (1) to provide all third parties with explicit and uniform provisions regarding the discounts, bonuses, prices, terms of payment, and credit limitations; and (2) to assure that any third party can purchase the merged entity's products in the amount and assortment required by the former. ${ }^{50}$ In another merger case the LVCA set out to address the portfolio effects stemming from the concentration of a wide range of products under the control of a dominant wholesaler. In view of the competition authority, the product portfolio as well as the terms and conditions of cooperation offered by the merging parties to the retail chains, could discourage the latter from switching the suppliers or acquiring certain products from the competing wholesalers. In order to mitigate the expected portfolio effects, the LVCA prohibited the merging parties from distributing or storing sparkling wines and "Martini" for the period of five years following the specified concentration. ${ }^{51}$

In Lithuania the alcoholic beverages market is notable for the fact that it was in this sector that for the first time the LTCA imposed structural remedies in a merger case. The concentration concerned the acquisition by Carlsberg of three Lithuanian breweries, which would bring the market share of the merged entity up to $60 \%$ of the beer production market (or more than $90 \%$ in the premium beer

\footnotetext{
48 AS A. Le Coq/OÜ Finelin, EECA (11.11.2003, no. 38-KO); see Kaarli Eichhorn, "The Estonian Competition Authority cleared a merger in the cider market with a commitment not to increase production above specified levels (A. Le Coq/Finelin)," e-Competitions 20956 (2003).

49 Interestingly enough, during the year following the concentration, the cider market experienced significant growth and due to the restriction on the production volumes, the main competitor of the parties to the concentration was able to significantly increase its market share. The EECA was asked to re-open the case and increase the limits on production volumes.

50 S.P.I. Worldwide Trade Limited/AV\&D SIA/Interlat SIA, LVCA (08.10.2007, no. 1300/07/06/18). It was noted that the LVCA's decision failed to specify how the second remedy should be implemented in practice i.e. it did not take into account the production capacities of the merged entity (see Dace SilavaTomsone, Ugis Zeltins, "The Latvian NCA cleared a merger in the alcoholic beverages distribution sector subject to remedies including granting of access to production and information (AV\&D)," e-Competitions 20992 (2007)).

51 SPV Distributor/S.D.V./L.D.V./MONO M/S.Alko, LVCA (19.06.2009, no. 651/09/06/4); see Zane Veidemane Bērzina, "The Latvian Competition Council approves acquisition by a holding company of a number of importers and distributors of alcoholic beverages after imposing conditions (SPV Distributor / MONO)," e-Competitions 32061 (2009).
} 
segment). ${ }^{52}$ As the harm to competition was obvious, the LTCA required the acquiring undertaking to divest one of the three breweries to an independent purchaser with the respective trademarks and other related rights of the divested business. ${ }^{53}$ Three years later the LTCA has reviewed another concentration, which involved the privatization of one of the four state-owned producers of alcoholic beverages. In that case the target undertaking was holding a share of more than $10 \%$ in another competitor and the LTCA feared that this shareholding could lead to anti-competitive coordination. While the merger was an important part of the privatization program, it was cleared with a condition that the acquirer would divest the specified shares. The behavioral segment of the imposed remedies consisted in the obligation to avoid discrimination (in pricing and other trading conditions) in transactions with the clients of the target undertaking. ${ }^{54}$ In 2004, in the context of another privatization of the state-owned producer of alcoholic beverages, the LTCA reached a similar conclusion and required the acquirer to divest its shareholding in a competitor in order to prevent anti-competitive coordination. ${ }^{55}$ Since in that case the creation or strengthening of dominant position was not an issue, the LTCA did not impose any behavioral remedies.

The coherent merger remedies practice of the Baltic NCAs in the market for alcoholic beverages can be explained by the competitive conditions described above. Partly due to the competitive pressure from foreign products, both EECA and LVCA have addressed the vertical foreclosure risks by accepting behavioral remedies. Structural remedies were employed by the LTCA only in cases of horizontal concentration of the producers, where individual production units could be divested to independent purchasers.

\subsection{CONSTRUCTION MATERIALS}

The typical structural setting on the markets for certain construction materials in the Baltics includes a dominant producer in the upstream market (for example, the production of cement). This creates a risk of input foreclosure or predatory

52 See OECD, Directorate for Financial and Enterprise Affairs, Competition Committee, Cross-Border Merger Control: Challenges for Developing and Emerging Economies, Contribution from Lithuania, supra note 45: 6.

53 Carlsberg/Kalnapilis et al, LTCA (09.11.2000, no. 123); see Agne Makauskaite, "The Lithuanian Competition Council cleared in phase II a merger in the breweries market with remedies, including divestiture and certain business behavioural commitments (Carlsberg/Kalnapilis at al.)," e-Competitions 21019 (2000).

54 Mineraliniai vandenys/Stumbras, LTCA (02.10.2003, no. 1S-107); see Agne Makauskaite, "The Lithuanian Competition Council cleared an acquisition in the market of distribution of strong alcoholic beverages with remedies, including divestiture and application of non-discriminatory pricing (Mineraliniai vandenys/Stumbras)," e-Competitions 21032 (2003).

55 Alita/ Anykščiu vynas, LTCA (27.05.2004, no. 1S-80); see Agne Makauskaite, "The Lithuanian Competition Council cleared an acquisition in the strong alcoholic beverages related market with divestiture remedy (Alita/Anykščiu vynas)," e-Competitions 21036 (2004). 
pricing in the downstream market (ready-mixed concrete). The issue of potential foreclosure has been addressed by the NCAs in abuse of dominance cases and taken into account in the merger control proceedings.

The Estonian merger control accounts for a single case where merger remedies were accepted in a construction materials merger. The merging parties were active in the market for production and sale of ready-mixed concrete. In addition to that, the acquirer had a dominant position in the market for the production and sale of cement, which is an input for the production of ready-mixed concrete. The EECA concluded that the notified concentration did not significantly restrict competition in the market for the production and sale of ready-mixed concrete. Nevertheless, it expressed general concerns regarding vertically affected markets. Although the EECA did not formally raise competition concerns in the vertically integrated markets, it recommended to the merging parties to assume an obligation to comply with the mandatory competition rules and treat the buyers belonging to the group and the buyers not belonging to the group equally in equivalent transactions (in other words, not to abuse their dominance). The parties have followed the EECA's recommendation and the clearance decision was issued with the public promise of the merging parties not to abuse their dominant position. ${ }^{56}$

The LVCA was faced with the task of preserving competition on the market for asphalt when a merger of two construction companies was notified in 2008 . The creation of dominance or substantial lessening of competition was viewed as unlikely because the amount of asphalt to be produced depended on the volume of construction works to be performed. Nevertheless, since competition on the market of road construction and maintenance was weak, the LVCA decided to safeguard the position of smaller competitors by imposing the following behavioral remedy. The merging parties were obliged to sell asphalt to all interested third parties on transparent and non-discriminatory terms and market prices. ${ }^{57}$ Although this remedy had to be maintained until July 2013 there were no reporting obligations attached to it.

In Lithuania, the merger remedies imposed on the market for construction materials concerned cement, an input used in the production of concrete and reinforced concrete. A vertical merger notified to the LTCA involved a dominant cement producer who could employ input foreclosure practices in order to exclude the competing producers of concrete. The type of remedy chosen by the LTCA to

\footnotetext{
${ }^{56}$ HeidelbergCement Northern Europe AB/part of NCC Roads Holding AB, EECA (07.08.2003, no. 26-KO). 57 AS A.C.B./AS 8 CBR, LVCA (02.06.2008, no. 3217/08/10/2); see Dace Silava-Tomsone, Ugis Zeltins, "The Latvian Competition Authority clears a merger in the roadworks sector subject to behavioural remedies relating to procurement and non-discrimination obligations (A.C.B. / 8 CBR)," e-Competitions 19966 (2008).
} 
address the potential anti-competitive effects of the concentration was behavioral: the merged entity was obliged to apply non-discriminatory pricing and other trading conditions in transactions with the third parties. ${ }^{58}$

The similarity of the competitive concerns in the market for construction materials pre-determined the identical remedies accepted by the Baltic NCAs. In each merger case where vertical input foreclosure was at issue, the competition authorities unanimously opted for behavioral commitments in the form of transparency and non-discrimination obligations.

\subsection{PHARMACEUTICALS}

Wholesale and retail trade in pharmaceuticals remains a highly regulated activity in all of the Baltic states. This partly explains why this economic sector has become so concentrated and difficult to penetrate by new entrants. Retail trade in pharmaceuticals can be provided only by pharmacies with corresponding licenses and it is not allowed to sell non-prescription medicines in any other retail locations. The wholesale level (in each of the three Baltic countries) is dominated by two market leaders, owning and/or supplying several pharmacy chains. This vertical integration (together with regulatory barriers) has contributed to the lessening of competition in the sector as a whole. Wholesalers operate in a market with a developed and stable supply channels and competition between them has become minimal. Large wholesalers have obtained a very strong market position in the marketing chain for pharmaceuticals, starting from the purchase of pharmaceuticals for the market until their sale to end consumers. A decline in the customer base for wholesalers is accompanied by another process - the number of pharmacy suppliers is diminishing, which leads to a similar product mix and price levels in different pharmacies and reduces competition. Thus, strengthening of the market power of a dominant/strong wholesaler will have a competition restricting effect on all levels of the market.

In 2008, the EECA prohibited a concentration in the market for trade in pharmaceuticals. ${ }^{59}$ This was the EECA's first prohibition decision. ${ }^{60}$ The prohibited concentration concerned the acquisition by the pharmacy chain Terve Pere Apteek

58 Betoneta/Markučiai, LTCA (25.09.2003, no. 1S-101); see Agne Makauskaite, "The Lithuanian Competition Council cleared a merger in the markets of concrete with remedies, including commitment of non-discriminatory pricing and various contractual provisions (Betoneta/Markučiai)," e-Competitions 21031 (2003).

59 Terve Pere Apteek OÜ/OÜ Saku Apteek, EECA (08.05.2008, no. 3.1-8/08-020KO); see Tanel Kalaus, "The Estonian Competition Authority issues its first merger prohibition taking into account both previous acquisitions and potential future acquisitions in the pharmacy services sector (Terve Pere Apteek/Saku Apteek)," e-Competitions 19964 (2008).

${ }^{60}$ In 2007 the EECA had arrived to a similar conclusion but the parties to the concentration decided to withdraw the merger notification before the final decision was made (see MM Holding B.V./OÜ Patrika, EECA (02.11.2007, no. 44-KO)). 
OÜ (that belonged to the largest wholesaler of pharmaceuticals in Estonia - AS Magnum) of a small pharmacy Saku Apteek OÜ. Although the target's market share was below $1 \%$, the concentration was prohibited due to the anticompetitive tendency. The undertakings belonging to the same group with the larger wholesalers of pharmaceuticals (AS Magnum and Tamro Eesti OÜ) acquired control of pharmacies, as a result of which, the supply channel was locked on the acquired pharmacies. Taking into account the sector-specific regulation of the pharmaceuticals market, the merger was prohibited with a purpose to stop the tendency leading to restriction of competition. It should be noted, however, that in the present case the merging parties did not propose any remedies.

In Latvia, the LVCA was faced with vertical integration in the pharmaceuticals sector in 2009 when the market leaders in the wholesale and retail segments of the market (40\% and 30\% respectively) notified their concentration. The merging parties were already cooperating within the framework of a marketing campaign that offered to the participating pharmacies certain quantity rebates. The LVCA was primarily concerned with the customer foreclosure scenario, which would exclude the competing wholesalers from a significant portion of the retail segment. The solution was found in a set of behavioral remedies: the LVCA obliged the merging parties not to prohibit pharmacies to participate in competing marketing campaigns and to offer only non-discriminatory volume discounts. In addition, in order to prevent further concentration on the retail segment of the market, the LVCA prohibited the merging parties from purchasing any other pharmacies in the four cities until 2012 (later extended until 2015). ${ }^{61}$

The concentration of the retail segment of the pharmaceuticals sector was addressed by the Lithuanian competition authority in 2011 in a horizontal merger of several pharmacies. The LTCA also focused its assessment on the specific geographic areas where pharmacies were competing for customers. In order to preserve competition, the LTCA ordered the merging parties to divest a number of pharmacies in those geographic markets. ${ }^{62}$

As the above analysis of the pharmaceutical markets in the Baltics demonstrates, all three countries have a highly concentrated wholesale segment where the wholesalers attempt to vertically integrate the retail segment by purchasing individual pharmacies. All three NCAs have adopted a similar approach to the possible vertical foreclosure risks: structural merger remedies aimed at

${ }^{61}$ Sentor Farm aptiekas/Recipe Plus, LVCA (23.01.2009, no. 2754/08/06/21); see Maris Butans, "The Latvian Competition Council provisionally agrees to clear a merger if behavioral remedies are adopted (Sentor Farm Aptiekas / Recipe Plus)," e-Competitions 26666 (2009).

${ }^{62}$ Gintarinè vaistinè/Saulègrąžu vaistinè and Thymus vaistinè, LTCA (07.10.2011, no. 1S-208). 
preventing the wholesalers from taking over the retail segment and eliminating independent pharmacies and pharmacy chains.

\section{CONCLUDING REMARKS}

The comparative analysis of the merger control statistics and the NCAs' approach to merger remedies in the selected markets demonstrate a high degree of coherence among the Baltic states. In all of the four selected markets characterized by similar competition concerns observed in all three target jurisdictions, the NCAs have been almost unanimously accepting the same types (structural or behavioral) of merger remedies. For example, the analysis of merger remedies in the markets for alcoholic beverages and construction materials demonstrates that Baltic NCAs have addressed vertical foreclosure risks with behavioral remedies in the form of transparency and non-discrimination obligations. In the highly regulated markets such as telecommunications and pharmaceuticals retail, where significant market entry barriers persist, the NCAs opted for structural solutions requiring the merging parties to divest the networks (telecom) or certain retail locations (pharmacies).

Both the statistical data on merger control enforcement and the comparative analysis of the particular markets indicate that there is no pre-determined preference for any type of remedies exhibited by the Baltic NCAs; rather they have been applied on a case-by-case basis. As suggested in the above mentioned works on competition law enforcement in small market economies, the NCAs in the Baltic countries demonstrated sufficient flexibility as far as the design of the appropriate remedies is concerned. ${ }^{63}$ This can partially support the above mentioned proposals that small market economies should be more prepared to apply behavioral remedies as an alternative to structural commitments.

Despite the formal harmonization of competition laws with the EU models and standards, the enforcement practice in the field of merger remedies in the Baltic states demonstrates a certain divergence from the approach outlined in the EU Remedies Notice. None of the Baltic NCAs has developed their own remedies guidelines and one would expect that the EU Remedies Notice is followed. However, unlike the EU Commission's preference for structural remedies as a one-time solution for structural problems caused by market concentration, the Baltic NCAs demonstrated their willingness to accept behavioral remedies as a solution for postmerger competition problems. Despite the EU Commission's emphasis on

\footnotetext{
63 As displayed in the comparative table of the Annex 1, in Latvia and Lithuania the proportion of behavioral remedies in the total number of merger remedies decisions is quite high. In Estonia this proportion is only $33 \%$ but any conclusions in relation to this jurisdiction would be premature due to very scarce experience with merger remedies (only 3 merger remedies decisions adopted in the reference period).
} 
effectiveness of the remedies, the decisions of the Baltic NCAs remain concise on the issues such as assessment, monitoring and implementation of merger remedies.

One of the strong arguments against such an approach to remedies would be the fact that in small concentrated markets where the NCAs have limited resources for monitoring the accepted behavioral commitments, the feedback and reaction by competitors and consumers becomes especially important. Unfortunately, this aspect is often neglected when the accepted behavioral remedies are described in a general and concise manner, which does not provide a clear understanding of remedies to the third parties.

The experience of the Baltic states with merger remedies suggests that more attention should be accorded to the quality of the assessment and monitoring of behavioral commitments, since they are being adopted in a substantial number of cases. In this respect a possible collaboration of the Baltic NCAs for the development of the common merger remedies guidelines, which would address the significant role of behavioral remedies in the merger control of these jurisdictions, should be encouraged. As far as the research community is concerned, the effectiveness of the remedies, especially behavioral ones, in the small market economies should be further explored in order to provide a more definitive assessment of the emerging tendencies identified in the present paper.

\section{ANNEX 1. MERGER REMEDIES STATISTICS}

\section{Estonia}

\begin{tabular}{|l|l|l|l|l|l|l|l|l|}
\hline Year/Type of decision & 2004 & 2005 & 2006 & 2007 & 2008 & 2009 & 2010 & 2011 \\
\hline Notifications received & 38 & 37 & 34 & 34 & 27 & 17 & 10 & 21 \\
\hline Total authorizations granted & 31 & 37 & 30 & 32 & 28 & 17 & 10 & 17 \\
\hline $\begin{array}{l}\text { Decisions containing } \\
\text { remedies }\end{array}$ & $\mathbf{1}$ & $\mathbf{1}$ & $\mathbf{0}$ & $\mathbf{0}$ & $\mathbf{0}$ & $\mathbf{0}$ & $\mathbf{0}$ & $\mathbf{1}$ \\
\hline Prohibition decisions & 0 & 0 & 0 & 0 & 1 & 0 & 0 & 1 \\
\hline
\end{tabular}




\section{Latvia}

\begin{tabular}{|l|c|c|c|c|c|c|c|c|}
\hline Year/Type of decision & 2004 & 2005 & 2006 & 2007 & 2008 & 2009 & 2010 & 2011 \\
\hline Notifications received & 6 & 15 & 26 & 77 & 53 & 9 & 6 & 10 \\
\hline Total authorizations granted & 6 & 15 & 25 & 76 & 50 & 9 & 6 & 9 \\
\hline $\begin{array}{l}\text { Decisions containing } \\
\text { remedies }\end{array}$ & $\mathbf{1}$ & $\mathbf{2}$ & $\mathbf{1}$ & $\mathbf{3}$ & $\mathbf{1}$ & $\mathbf{1}$ & $\mathbf{3}$ & $\mathbf{2}$ \\
\hline Prohibition decisions & 0 & 0 & 0 & 1 & 2 & 0 & 0 & 0 \\
\hline
\end{tabular}

\section{Lithuania}

\begin{tabular}{|l|l|l|l|l|l|l|l|l|}
\hline Year/Type of decision & 2004 & 2005 & 2006 & 2007 & 2008 & 2009 & 2010 & 2011 \\
\hline Notifications received & 56 & 64 & 61 & 78 & 54 & 42 & 40 & 46 \\
\hline Total authorizations granted & 54 & 59 & 59 & 74 & 52 & 47 & 33 & 49 \\
\hline $\begin{array}{l}\text { Decisions containing } \\
\text { remedies }\end{array}$ & $\mathbf{3}$ & $\mathbf{2}$ & $\mathbf{1}$ & $\mathbf{2}$ & $\mathbf{2}$ & $\mathbf{1}$ & $\mathbf{0}$ & $\mathbf{1}$ \\
\hline Prohibition decisions & 0 & 0 & 0 & 1 & 0 & 0 & 0 & 0 \\
\hline
\end{tabular}

\section{Comparative table}

\begin{tabular}{|c|c|c|c|c|}
\hline Country & Notifications & Remedies & $\begin{array}{c}\text { Behavioral } \\
\text { remedies }\end{array}$ & $\begin{array}{c}\text { Behavioral } \\
\text { remedy share }\end{array}$ \\
\hline Estonia & 218 & 3 & 1 & $33 \%$ \\
\hline Latvia & 201 & 14 & 9 & $64 \%$ \\
\hline Lithuania & 441 & 12 & 6 & $50 \%$ \\
\hline
\end{tabular}

\section{BIBLIOGRAPHY}

1. Baarslag, Marieke, Gulbahar Tezel, and Saskia Weerheim. "The Dutch merger remedy experience." E.C.L.R. 30(9) (2009): 447-469.

2. Black, Oliver. "Competition law in Central and Eastern Europe." E.C.L.R. 14(3) (1993): 129-134.

3. Butans, Maris. "The Latvian Competition Council provisionally agrees to clear a merger if behavioral remedies are adopted (Sentor Farm Aptiekas / Recipe Plus)." e-Competitions 26666 (2009).

4. Calvino, Nadia. "When do Mergers Raise Concerns? An Analysis of the Assessment Carried out by the European Commission under the New Merger Regulation." Journal of European Competition Law \& Practice 2(6) (2011): 521-528. 
5. Eichhorn, Kaarli. "The Estonian Competition Authority cleared a merger in the cider market with a commitment not to increase production above specified levels (A. Le Coq/Finelin)." e-Competitions 20956 (2003).

6. Eichhorn, Kaarli. "The Estonian Competition Authority clears a merger in phase II in the markets of wholesale broadband access and retail broadband access with divestiture remedies (Elion/MicroLink)." e-Competitions 20953 (2005).

7. Gal, Michal S. Competition Policy for Small Market Economies. Harvard University Press, 2003.

8. Gal, Michal S. "Merger Policy for Small and Micro Jurisdictions": 61-124. In: More Pros and Cons of Merger Control. Konkurrensverket, 2012.

9. Gal, Michal S. "Size Does Matter: General Policy Prescriptions for Optimal Competition Rules in Small Economies." Southern California Law Review 74 (2000-2001): 1437-1478.

10. Geradin, Damien, and David Henry. "Competition Law in the New Member States - Where Do We Come From? Where Do We Go?": 273-309. In: Damien Geradin, ed. Modernisation and Enlargement: Two Major Challenges for EC Competition Law. Intersentia, 2005.

11. Ginter, Carri and Mari Matjus. "Assessment of non-horizontal mergers in Estonia." E.C.L.R. 31(12) (2010): 504-508.

12. Hoehn, Thomas and Suzanne Rab. "UK merger remedies: convergence or conflict with Europe? A comparative assessment of remedies in UK mergers." E.C.L.R. 30(2) (2009): 74-94.

13. Hoehn, Thomas, Suzanne Rab, and Grant Saggers. "'Breaking up is hard to do': National merger remedies in the information and communication industries." E.C.L.R. 30(5) (2009): 255-276.

14. Horn, Henrik, and Johan Stennek. "EU merger control and small member states interests": 83-119. In: Pros and Cons of Merger Control. Konkurrensverket, 2002.

15. Kalaus, Martti. "Estonia: the new Competition Act introduces full merger control." E.C.L.R. 23(6) (2002): 304-310.

16. Kalaus, Tanel. "The Estonian Competition Authority issues its first merger prohibition taking into account both previous acquisitions and potential future acquisitions in the pharmacy services sector (Terve Pere Apteek/Saku Apteek)." e-Competitions 19964 (2008).

17. Këllezi, Pranvera, and Christophe Rapin. "Merger remedies and competition law: An overview of EU and national case law." e-Competitions 43382 (2012). 
18. Little, Cormac. "Remedies under Irish merger control rules." E.C.L.R. 30(12) (2009): 600-603.

19. Makauskaite, Agne. "The Lithuanian Competition Council cleared an acquisition in the market of distribution of strong alcoholic beverages with remedies, including divestiture and application of non-discriminatory pricing (Mineraliniai vandenys/Stumbras)." e-Competitions 21032 (2003).

20. Makauskaite, Agne. "The Lithuanian Competition Council cleared an acquisition in the strong alcoholic beverages related market with divestiture remedy (Alita/Anykščiu vynas)." e-Competitions 21036 (2004).

21. Makauskaite, Agne. "The Lithuanian Competition Council cleared a merger in the markets of concrete with remedies, including commitment of nondiscriminatory pricing and various contractual provisions (Betoneta/Markučiai)." e-Competitions 21031 (2003).

22. Makauskaite, Agne. "The Lithuanian Competition Council cleared in phase II a merger in the breweries market with remedies, including divestiture and certain business behavioural commitments (Carlsberg/Kalnapilis at al.)." eCompetitions 21019 (2000).

23. Makauskaite, Agne. "The Lithuanian Competition Council clears a merger in the fixed, mobile and other related telecommunications markets with a commitment to notify any further structural changes (Telia/Sonera)", eCompetitions 21023 (2002).

24. Makauskaite, Agne. "The Lithuanian Competition Council clears a concentration in the wholesale and retail markets for broadband services with structural and behavioural remedies (Elion/MicroLink)." e-Competitions 21037 (2005).

25. Makauskaite, Agne "The Lithuanian Competition Council clears in phase II a merger in the markets of fixed and mobile communications with structural and behavioural remedies (TeliaSonera/Omnitel)." e-Competitions 21033 (2003).

26. Malinauskaite, Jurgita. "Development of merger control in the Baltic countries: over 10 years of experience: Part 1." E.C.L.R. 32(3) (2011): 77-85.

27. Malinauskaite, Jurgita. "Development of merger control in the Baltic countries: over 10 years of experience: Part 2." E.C.L.R. 32(3) (2011): 109-115.

28. Malinauskaite, Jurgita. "Efficiency tests in the merger control regimes of the Baltic countries: myth or reality." I.C.C.L.R. 18(4) (2007): 136-146.

29. Paas, Katri. "Implications of the Smallness of an Economy for Merger Remedies." Juridica International XV (2008): 94-103. 
30. Paas-Mohando, Katri. "Do Small Economies Need Specific Rules for Substantive Aspects of Merger Control?" E.C.L.R. 34(5) (2013): 260-266.

31. Silava-Tomsone, Dace, and Ugis Zeltins. "The Latvian NCA clears a merger in the telecommunications sector with remedies including granting of access to infrastructure (Telia Sonera)." e-Competitions 20973 (2002).

32. Silava-Tomsone, Dace, and Ugis Zeltins. "The Latvian NCA cleared a merger in the alcoholic beverages distribution sector subject to remedies including granting of access to production and information (AV\&D)." e-Competitions 20992 (2007).

33. Silava-Tomsone, Dace, and Ugis Zeltins. "The Latvian Competition Authority clears a merger in the roadworks sector subject to behavioural remedies relating to procurement and non-discrimination obligations (A.C.B. / 8 CBR)." e-Competitions 19966 (2008).

34. Silava-Tomsone, Dace, and Ugis Zeltins. "The Latvian Competition Council clears a merger in the markets for data transmission services and Internet access services subject to divestiture remedies (Lattelecom/Microlink Latvia)." e-Competitions 20979 (2005).

35. Svetlicinii, Alexandr, and Külliki Lugenberg. "Merger remedies in a small market economy: the Estonian experience." E.C.L.R. 33(10) (2012): 475-481.

36. Thielert, Julia, and Maarten Pieter Schinkel. "Estonia's competition policy: a critical evaluation towards EU accession." E.C.L.R. 24(4) (2003): 165-175.

37. Veidemane Bērzina, Zane. "The Latvian Competition Council approves acquisition by a holding company of a number of importers and distributors of alcoholic beverages after imposing conditions (SPV Distributor / MONO)." eCompetitions 32061 (2009).

38. Virtanen, Dalia. "The new Competition Act in Lithuania." E.C.L.R. 21(1) (2000): 30-36.

\section{LEGAL REFERENCES}

1. Alita/Anykščiu vynas. LTCA, 27.05.2004. No. 1S-80.

2. AS A.C.B./AS 8 CBR. LVCA, 02.06.2008. No. 3217/08/10/2.

3. AS A. Le Coq/OÜ Finelin. EECA, 11.11.2003. No. 38-KO.

4. Betoneta/Markučiai. LTCA, 25.09.2003. No. 1S-101.

5. Carlsberg/Kalnapilis, et al. LTCA, 09.11.2000. No. 123.

6. Commission Notice on remedies acceptable under the Council Regulation (EC) No 139/2004 and under Commission Regulation (EC) No 802/2004. Official Journal, 2008, no. C 267. 
7. Competition Act of the Republic of Estonia. Official Gazette, 2001, no. 56, 332.

8. Competition Commission, CC8 - Merger Remedies: Competition Commission Guidelines (November 2008) // http://www.competitioncommission.org.uk/assets/competitioncommission/docs/pdf/noninquiry/rep_pub/rules_and_guide/pdf/cc8.pdf (accessed February 2, 2013).

9. Elion Ettevõtted AS/MicroLink AS. EECA, 21.10.2005. No. 47-KO.

10. Elion/MicroLink. LTCA, 27.10.2005. No. 1S-122.

11. Gintarinè vaistinè/Saulègrąžu vaistinè and Thymus vaistinè. LTCA, 07.10.2011. No. 1S-208.

12. HeidelbergCement Northern Europe AB/Part of NCC Roads Holding AB. EECA, 07.08.2003. No. 26-KO.

13. Hoffmann-La-Roche \& Co. AG v Commission. CJEU, 1979. No. 85/76.

14. ICN Merger Working Group: Analytical Framework Subgroup, Merger Remedies Review Project. Report for the fourth ICN annual conference (June 2005) //

http://www.internationalcompetitionnetwork.org/uploads/library/doc323.pdf (accessed February 2, 2013).

15. Lattelecom SIA/Microlink Latvia SIA. LVCA, 30.09.2005. No. 497/05/10/3.

16. Mineraliniai vandenys/Stumbras. LTCA, 02.10.2003. No. 1S-107.

17. MM Holding B.V./OÜ Patrika. EECA, 02.11.2007. No. 44-KO.

18. OECD Directorate for Financial and Enterprise Affairs, Competition Committee. Cross-Border Merger Control: Challenges for Developing and Emerging Economies, Contribution from Lithuania. Document DAF/COMP/GF/WD(2010)74 (December 2010) // http://kt.gov.It/naujienos/docs_oecd/global_forum_2011_1.pdf (accessed February 2, 2013).

19. OECD Directorate for Financial and Enterprise Affairs, Competition Committee. Merger Remedies. Document DAF/COMP/WP3(2011)2 (October 2011).

20. OECD Directorate for Financial and Enterprise Affairs, Competition Committee. Merger Remedies. Document DAF/COMP(2004)21 (December 2004) // http://www.oecd.org/competition/mergers/34305995.pdf (accessed February 2, 2013).

21. Regulation No. $139 / 2004$ On the Control of Concentrations Between Undertakings. Official Journal, 2004, L24/1.

22. Sentor Farm aptiekas/Recipe Plus. LVCA, 23.01.2009. No. 2754/08/06/21.

23. S.P.I. Worldwide Trade Limited/AV\&D SIA/Interlat SIA. LVCA, 08.10.2007. No. $1300 / 07 / 06 / 18$. 
24. SPV Distributor v. S.D.V./L.D.V./MONO M/S.Alko. LVCA, 19.06.2009. No. 651/09/06/4.

25. Telia AB/Sonera Corporation. EECA, 25.09.2002. No. 58-KO.

26. Telia/Sonera. EU Commission, 2002. No. COMP/M2803.

27. Telia/Sonera. LTCA, 18.07.2002. No. 82.

28. TeliaSonera/Omnitel. LTCA, 11.12.2003. No. 1S-140.

29. Telia/Sonera/Swedgiro AB. LVCA, 13.08.2002. No. 124.

30. Terve Pere Apteek oü/OÜ Saku Apteek. EECA, 08.05.2008. No. 3.1-8/08$020 \mathrm{KO}$.

31. United Brands Company and United Brands Continentaal BV v Commission. CJEU, 1978. No. 27/76.

32. US Department of Justice, Antitrust Division. Policy Guide to Merger Remedies (June 2011) // http://www.justice.gov/atr/public/guidelines/272350.pdf (accessed February 2, 2013). 